\title{
Analysis of College Students' Information Quality and Study on Correspondence and Education System in "Internet+ " Era
}

\author{
Han Li \\ Library \\ Qilu University of Technology \\ Jinan Shandong \\ hanli1027@163.com
}

\begin{abstract}
This article pays attention to the basal connotation of information quality and did plenty of surveys and analyses about the contemporary undergraduates. Base on the new requests of training the information quality of college students in the age of" "Internet+", it explains the necessity of creating a new kind of education system of the information quality for the students in some advanced colleges and the possibility to start rebuilding the education system of information quality. Besides, it brings up some recapitulative strategies. It incorporates the education of information quality into the system of training the comprehensive quality of the college students and divides it into three stages including adaptation education, general education and practice experience, which is creative.
\end{abstract}

Keywords_-“Internet+"; college student; information quality

\section{INTRODUCTION}

The age of "Internet+" refers to a generation in which information production and use technology are totally advanced. Its feature can be called Mobile Communication \& Internet. In 2015, Premier $\mathrm{Li}$ proposed the concept of "Internet + " in the report on the work of government for the first time. It can be generalized as follows: To facilitate the combination between mobile Internet, Cloud Computing, massive data, Internet of Things and modern manufacturing industry as well as to facilitate the healthy development of the e-business, industrial Internet and Internet finance. It means "Internet + " has been incorporated into the top-level design and has became a significant strategy of the development of state economy and society. "Internet + " depends on the accumulation and application of information knowledge and Internet technology, so it requests contemporary college students to have relevant information quality[10]. In the university, fasting education of information quality is supposed to be an important part of strengthening comprehensive quality education towards college students[2].

\section{The CONNOTATION OF COLlEgE STUdENTS' INFORMATION QUALITY[6]}

According to the definition from Baidu Baike (a Chinese version of Wikipedia) information quality is the ability to acquire, evaluate and use knowledge information resource. It's a new quality which develops based on the physical quality, psychological quality and sociocultural quality etc[1]. It's also a high requirement towards human in the information age. It's a necessary skill that teaches modern talents how to acquire, process and take use of knowledge information in the information situation[3].

The information quality of college students is mainly reflected in three aspects.

\section{A. Knowledge Awareness}

As the most active and the most enthusiastic group in the society, the core of college students' information awareness is the updated informational idea and scope[7]. What's more, it includes the positive competition awareness to obtain information resource, the awareness of hardship faced with the accelerating tendency of the world informational process and the awareness to learn constantly and learn for life on the condition that technology is increasing and knowledge is updating.

\section{B. Information Ability}

Information ability is the main aspect of information quality, including the gather and filter towards the information, the communication evaluation judgment and processing towards the information, the tracing and application towards the information technology, and the information security and protection[8]. As for the college students, different people may deal with the same information source in different ways[4]. Consequently, the quality quantity and usage effect they gained may badly differ.

\section{Information Virtue}

Information virtue refers to people's virtue and behavior in the information activity[9]. It is the sum of adjusting information process, information deliver, information usage and some relevant behavior rules. Along with the network technology, information is rapidly increasing. At the same time the laws and rules are not complete in the aspect of Internet, which comes into a rigid challenge towards young undergraduates. They may not know what they should do in the process of selecting a lot of information. Facing the Virtue question such as academic plagiarism and privacy security, they may do some careless behavior. We start the education of information Virtue in order to make college students learn 
about the moral requirements and legal rules about this aspect, and increase the moral level of information work.

\section{INVESTIGATION AND ANALYSIS OF INFORMATION QUALITY OF COLLEGE STUDENTS}

To understand the current situation of information quality of college students, we carried out a survey activity in the form of a random survey in the Changqing University Science Park area.2000 questionnaires were handed out and 1549 valid questionnaires were returned, covering majors which included science and arts, art, economics, management, law and so on. In this survey, first-year students as the main body account for $70.4 \%$.

\section{A. Situation and Results of Questionnaires}

About the information consciousness, $75.9 \%$ of students had access to computers before entering the university, and $64.1 \%$ of students have strong senses of their own information. To obtain the required knowledge, they often actively search for information. In terms of ways of information access, network and library obviously have a large proportion, $42 \%$ and $37.5 \%$, respectively. About the information ability, more than $50 \%$ of the students think that the library should be a major source of information and knowledge, but very few people are familiar with specific service projects and service functions of the library. $82 \%$ of people know bibliographic queries, but people know the inter library loan, the original transfer and other services are less than $7 \%$. Besides, the number of people who use specialized databases of the library to retrieve information is very low. When as for how to understand and confirm unfamiliar information sources, students' decisions (choices) are shown in Table I. (This question has multiple choices)

TABLE I. PROPORTION OF MULTIPLE CHOICES

\begin{tabular}{|l|c|c|}
\hline \multicolumn{1}{|c|}{ The select way } & $\begin{array}{c}\text { the number of } \\
\text { people }\end{array}$ & $\begin{array}{c}\text { the } \\
\text { proportion }\end{array}$ \\
\hline Internet search & 1140 & $80 \%$ \\
\hline Advice to teachers and students & 1115 & $72 \%$ \\
\hline Read books on paper & 711 & $45.9 \%$ \\
\hline Access to electronic books & 181 & $11.7 \%$ \\
\hline Using professional database & 109 & $7 \%$ \\
\hline
\end{tabular}

About the Information morality, for solutions to the discovery process on a public computer virus file, $29.95 \%$ of people choose to notice the room administrator, $65.6 \%$ say they will not copy or forward while $3.1 \%$ say they do not care, only $1.3 \%$ of people think they may copy or forward. When it comes to attitudes of dealing with the hacker, $48.1 \%$ of students say that if he is a computer expert, he is willing to participate to stop hacker attacks, $13.5 \%$ of people said that, if possible, they will experience to be hackers, and another $38.4 \%$ of people do not care about that as long as they are not be attacked. For information on IP network problems, 50.1\% of students say they know the problem exists, but there is no way we have cited, only $13.5 \%$ of people expressed their concerns, others don't think about it or say that does not matter.

\section{B. Analysis of the survey results}

For current students, a large amount of information is always around them. Most of the students have their own computers, the proportion of surfing the internet with cell phones almost $100 \%$, many students' learning, living and the social life achieve full networking, and they even form the network-dependent, there have been a number of "mobile phone overuse". However, owning computers but failing to dig a major role of the computer, and occupying the network rather than make full use of network information resources, which has become a common feature of many college students. This survey clearly shows students basic information about the quality of health. In the information awareness, as well as the improvement of universal primary and the popularity of middle and primary schools' IT curriculum, almost all students have demands in the information area, more than $60 \%$ of the students show a keen interest on the information technology and the information knowledge. Nonetheless, for many people, the concept of information is too shallow, the role of the computer is to chat, play games, and watch films, in addition to re-look common pages.

In the information capacity, in view of the spread of information and network technology, accesses for college students to obtain professional information is very large. Not only has been the construction of the library condition basically covered by the network, but also its functions are improving gradually, and the library is also an information source that makes students willing to visit. But most students only have a primary retrieval capability, most people use online search engines to get information while students lack the understanding of professional resources and means of the library, thus they seldom use them. Of course, this is also concerned with the students surveyed who are mostly freshmen, since literature retrieval course of many schools was opened in the second, or even the third year, so many students lack professional knowledge of the literature search.

In terms of the information morality[5], most of the students hold a clear attitude in dealing with hackers and virus file, indicating that there is a strong self-discipline, but there are also a small amount of students with ambiguous attitudes. They even reveal adventurous psychology because of curiosity, which shows that their sense of responsibility and selfdiscipline is not strong enough. On the issue of intellectual property network, many students lack sufficient knowledge, and they seldom concern disputes triggered by online intellectual property. Therefore, students need to strengthen the study of interpretation of relevant laws and regulations to increase their knowledge reserves.

Overall, current students' information quality is not optimistic. The ordinary and general level of information needs is contrasted out of a stronger sense of information. Not only do students lack the initiative to enhance their social competitiveness by carrying out the study practice with network tools, but also do not have strong abilities of obtaining information. Searching for professional information technology lacks of recognition, so that electronic resources of 
Library and Information what the schools have built with much money devoted are useless; college students' selfconsciousness has more obvious manifestations in the information morality and the information quality. Nearly $25 \%$ of the adults make a difference in some important issues which aren't related to them, and they lack a sense of responsibility. What's more, their legal awareness and knowledge of online intellectual property rights are not enough.

\section{NECESSITY AND FEASIBILITY OF "INTERNET + " FOR COLLEGE STUDENTS IN THE INFORMATION LITERACY EDUCATION SYSTEM CONSTRUCTION OF CORRESPONDENCE USING THE TEMPLATE}

A. "Internet +" Time Has Put Forward the New Demands for Students' Information Literacy

"Internet + " is the new ecologically economic development model symbolized by the combination of the mobile communication and network as the main indicator, and application developers are the protagonist of this model. "Internet + " has the character as decentralized, open access, equality and cooperation, sharing boundlessly, multi-node network, fast response. It has low entry barriers, so that everyone can enter the era of entrepreneurial behavior and can offer the opportunity to become a legend. Our age has brought up the opportunities while challenges sprang out. New Requirements of "Internet + " for Students Information literacy are the following:

First, a strong and keen sense of information is needed, and sufficient sensitivity and sustained attention are devoted to the information resources. With time rapidly changing, this will become the internal driving force for a person to adapt to environmental information, and realize personal values .

Second, a powerful information search and access capabilities for comprehensive and rapid use of various Internet searching engines, specialized search tools and a variety of electronic resources. Thus vast amounts of information can be searched, stored, and managed by category.

Third, the ability to evaluate and organize good information resources in a broad array of information items is essential, as is to refine, implement effective screening and evaluation of information.

Fourth, the ability of excellent information processing, innovation and the ability to use that value to fully exploit the information obtained, and digesting, making adjustment to promote knowledge and resources reserves, while the relevant information processing, their innovative ideas can be added, last but not the least, try to use the network interactive tools to spread and exchange with others .

Fifth, good information quality, moral sense of responsibility, awareness of the law, and legitimate use of the network of information and knowledge resources, while respecting the shared rights and privacy of others. Dissemination of useful information, while resistance against unhealthy information, and maintain the information security.

\section{B. "Internet + " Time for Students' Information Literacy Education proposed a new task}

Miller in the book "Culture and Commitment", interpreted that the information age brought up the formation of a figurative culture and post- figurative culture, and the former refers to that learning metaphor occurs between peers, and the latter, it refers to the elders learn from the younger generation in turn. This "Internet +" period has been revealed, ultrafast updated information knowledge and technology inspire more and more younger generation to lead the forefront of the trend and the era of advancement and development. Thereby considering the university education which is facing, many new missions and tasks in the implementation of the Information Literacy Education.

First, on the target level of education adjustments is supposed to be made. Our last course teaches literature retrieval which is the existed information and knowledge to enable students to learn, understand and apply knowledge and skills to search for information and documentation utilized; And now, on the basis of improving the basic knowledge, skills, information and moral culture, our educational goal is to teach students to collect, collate, evaluate, and produce innovative use of information and knowledge, the training aims to create innovative and informational quality.

Second, it is some adjustment in the educational content. Traditional library is a collection of traditional printed literature teaching students to use information resources focused on knowledge of the literature search and use. With the progress of network and information technology, the information environment and resources reserves have changed fundamentally. We currently should make students master traditional literature via capacity, and have a good understanding of various electronic media information, particularly improve computer operation and application capacity, also to familiar and participate in Internet and the mobile Internet using process; Set information resources shared of concept, actively adapt and integrate into globalization network information resources system, using series of information retrieved tool to get effective information and to solve their own problems.

\section{C. "The Internet +" Time Vision of System Reconstruction for University Students ' Information Quality Education}

Information quality education system should adapt to the current trend of information, network, mobile Internet, and fully embody the "Learning Center" scenarios; the combination of education and experience can establish a clear structure and interactive, flexible and open education teaching system. To sum up, the education system is divided into three parts: adaptation to the education, general understanding education, and practical experience.

Adaptation of information quality education should start in the first year, which is quite different from the current standard of sophomore or junior open practice of literature retrieval course, when students are enrolled at the beginning, they should learn about information platform and related resources, namely the use of library, network-center analysis and other forms so as to improve students' information consciousness and inspire their information needs. In this 
session, library and Internet Center staff is that of lecturer, and platform is the classroom, designing and training need to be done in the educational processing order to bring the nonclassroom education to classroom education. Information quality education should be started in grade one late or second grade. General education is to be improved on the basis of literature retrieval course in the original, focuses on students ' information literacy basic skills, information and moral education, so that they have better access to information, preservation, management, organizational and communication skills, and can follow the laws and regulations of information dissemination, awareness of resisting crime and intellectual property protection will be formed eventually. In this section, the course content is highly important; Therefore, it is necessary to reform the teaching content and methods.

Information literacy practice experience should start in junior and senior grades. Which can be realized by two article paths: one is to combine with the students' professional courses phase, to make the work like information searching, inquiry joint with the books professional data resources professional courses, cultivating students' ability to use information retrieval tools to make them understand the situation of library information resources in storage, master the law of global networks to connect to. Second, combined with the practice of college students' innovation and entrepreneurship activities: according to the needs of scientific and technological innovation projects, the provision of targeted scientific and technical information, information gathering, screening, processing and utilization of guidance and services, such as helping students to apply for patents or publishing papers; and in the view of college students' need. On entrepreneurial action in school, students should foster awareness of information, improve the skill of Internet+ service, + profession, thus to make good information quality become the big edge.

\section{CONCLUSION}

"The Internet + " era of the University campus, is full of bad manufacture and dissemination of information, contains vast amounts of information, convenient resource through entrepreneurial passion and practice characteristic of the information age innovation, how to adapt to the new situation and achieve self-development are the test for college students ' information quality and consideration. Qilu University of Technology takes the lead in implementing "dual credit" talent training model, in addition to normal academic credits, establishing an integrated quality and evaluation of credits system, the growth and development of the students will form a project included, by all means, information quality will take effect as an important component. Combined with the features and requirements of the times, to understand the information quality education of college students, to reform and innovate the original mode of education, as is inevitable for higher education, and inspire students to lead the innovation and entrepreneurship culture, which will be the effective ways to enhance the ability to adapt to economic and social development.

"Only through the direct participation of the young generation, and using their extensive and novel knowledge, can we build a future full of vitality". This is Miller's conclusion in the Culture and Commitment. And our innovative information literacy education mode and enhancement of the level of university students' information quality will represent our final aim.

\section{REFERENCES}

[1] http://baike.baidu.com/link?url=2_UwMLrJWIC3nOY7dYZCuJZHIhp XAH6GCjA-sTV4QJriz31 watQxPZ7Kr516b5KG38dHxes0tuFe-kD-ncs AZKJ.

[2] Margaret, Miller. Culture and Commitment [M]. Hebei People's Publishing House, 1987.

[3] N Zhao, Engineering Students' Information Literacy Education Curricula System Construction. J. Library Forum, vol. 2, pp. 147-148, August 2009 .

[4] Z L Hu, Role-Playing of Digital Library in the Information Quality Education in Colleges and Universities. J. Journal of Academic Theory, vol. 9, pp. 210-213, August 2010.

[5] C G Xing, Analysis on the Information Ethics and the Information Morality. J. Sci-Tech Information Development \& Economy, 2015.

[6] X L Liu, ON EDUCATION INFORMATIZATION AND TRAINING FOR THE COLLEGE STUDENTS' INFORMATION QUALITY. J. Nuclear Power Engineering, vol. 31(2), pp. 3693-3696, 2010.

[7] J Z L Zhang, Analysis of the influencing factors of College Students' information cognition under the new media environment Based on the Analytic Hierarchy Process. J. Journal of Modern Information, 2013.

[8] W J Ren, T J Zhang, et al. The Empirical Analysis of Information Ability System in Chinese Enterprises. J. Energy Procedia, vol13,pp.1486-1492.2010

[9] J Chen, Y L Chen, F L Xu, et al. Medical Education Model with Core Competency as Guide, Evidence-Based Medicine as Carrier and Life Learning as Purpose(4): Effects of Evidence-Based Medicine Course on Improvement of Information Consciousness and Morality for Medical Students[J]. Chinese Journal of Evidence-Based Medicine, 2012, 12(1):31-37.

[10] Sang Y. Study on the path of constructing statistical system in modern service-oriented enterprises on "Internet $+"$ background[J]. Acta Tabacaria Sinica, 2015. 